\title{
Nitrogen mineralization in semi-arid rangeland: influence of grazing and land use type
}

Gul Bano ${ }^{1 *}$, Muhammad Islam ${ }^{2}$, Mufakhirah Jan Durrani ${ }^{1}$, Shamim Gul $^{1}$, Amna Bano ${ }^{3}$, Basira Akhtar ${ }^{1}$ and Shafi Muhammad ${ }^{4}$

1. Department of Botany, University of Balochistan, Quetta-Pakistan

2. National Agriculture Research Center Islamabad-Pakistan

3. Department of Chemistry, University of Balochistan, Quetta-Pakistan

4. Faculty of Pharmacy, University of Balochistan, Quetta-Pakistan

*Corresponding author's email: gulbano_rehman@yahoo.co.uk

Citation

Gul Bano, Muhammad Islam, Mufakhirah Jan Durrani, Shamim Gul, Amna Bano, Basira Akhtar and Shafi Muhammad. Nitrogen mineralization in semi-arid rangeland: influence of grazing and land use type. Pure and Applied Biology. Vol. 5, Issue 4, pp987-995. http://dx.doi.org/10.19045/bspab.2016.50124

\begin{tabular}{llll}
\hline \hline Received: 21/05/2016 & Revised: 30/08/2016 & Accepted: 03/09/2016 & Online First: 05/09/2016 \\
\hline
\end{tabular}

\section{Abstract}

Mineralization of nitrogen $(\mathrm{N})$ in soil is an important process that controls life on earth. In this study, the monthly pattern of soil mineralization was assessed by using intact soil incubation cores in the upper soil layer $(0-15 \mathrm{~cm})$. The experiment was conducted in semi-arid rangeland of Tomagh, Balochistan, Pakistan in three land use types: protected, orchard and grazed. The study was conducted from May 2009 to April 2010. Results showed that there was highly significant $(\mathrm{P}<0.01)$ response in $\mathrm{N}$-mineralization, $\mathrm{N}$-ammonification, and $\mathrm{N}$-nitrification both on monthly and land used basis. The $\mathrm{N}$-mineralization, $\mathrm{N}$-ammonification and $\mathrm{N}$-nitrification were higher during growing season in the months where there was higher rainfall. Maximum mineralization $\left(0.7602 \mu \mathrm{g} \mathrm{g}^{-1}\right)$, ammonification $\left(0.7482 \mu \mathrm{g} \mathrm{g}^{-1}\right)$ and nitrification $\left(0.4879 \mu \mathrm{g} \mathrm{g}^{-1}\right)$ occurred in orchard area, whereas minimum for the same attributes were recorded in grazed area $(0.0291$, 0.0200 and $0.0091 \mu \mathrm{g} \mathrm{g}^{-1}$ respectively). In conclusion, the temperature and moisture of soil were found to be controlling factors for $\mathrm{N}$-cycling. Moreover, grazing in Tomagh semi-arid rangeland exerted significant negative influence on N-cycling.

Keywords: Semi-arid; Ammonification; Nitrogen; Mineralization

Introduction

While considering the materialistic substance, it can be said that the most abundant elements on earth is Nitrogen (N). For the life to exist 2 to 20 per 100 carbon atoms are present in different life form [1]. In soil the available $\mathrm{N}$ exists in different organic forms of nitrogen, like nitrate $\left(\mathrm{NO}_{3}{ }^{-}\right)$ and ammonium $\left(\mathrm{NH}_{4}^{+}\right)$. The range of $\mathrm{N}$ quantity present in vegetation is from 1-240 $\mathrm{g} \mathrm{N} / \mathrm{m}^{2}$ [2]. The $\mathrm{N}$ mineralization in soil plays an important role in its bioavailability of $\mathrm{N}$ to plants and soil microorganisms in many ecosystems [3, 4]. It influences soil fertility [5, 6], plant growth [7] and primary production [8]. This is the biological process of conversion of organic $\mathrm{N}$ to inorganic forms i.e. nitrate $\left(\mathrm{NO}_{3}{ }^{-}\right)$and ammonium $\left(\mathrm{NH}_{4}{ }^{+}\right) . \mathrm{N}$ mineralization is influenced by many factors such as plant and microbial 
biomass, moisture and temperature of soil [9]. In the soil sulfur, $\mathrm{N}$ and phosphorous are present more than $90 \%$ in organic form [2]. Especially nitrogen is usually a limiting factor for plants amount other nutrients in arid and semi-arid regions [10, 11]. A watery soil not saturated but moist and warm is quite suitable for fast mineralization. Variation of seasonal and temporal nature for $\mathrm{N}$ cycling is reported in grassland [12], forest [10] and other ecosystems $[13,14]$ in both growing season [15] and non-growing season [16, 14]. Nitrogen undercurrents in terrestrial ecosystems can be expected by the influence of soil's moisture and temperature and their interactions to $\mathrm{N}$ mineralization. Plant biomass over earth is influence by grazing, likewise herbivores alter physiology of soil by crushing [16] which change mineralization rates of $\mathrm{N}$, by affecting severely soil organisms activities $[17,18]$. In arid and semi-arid rangelands $\mathrm{N}$ mineralization is influenced by the reducing soil organic carbon contents and microbial biomass because soil being compact due to trampling [19]. Soil compaction also occurs by grazing which influences negatively $\mathrm{N}$ cycling by changing water infiltration and aeration [20]. In this study seasonal bases scrutiny of the mineralization of nitrogen in soil of such area which is under grazing, protection (ungrazed) and orchard areas is targeted. The main reason to select an orchard site was to enquire whether the site without animal interference can have greater $\mathrm{N}$ mineralization or not.

\section{Materials and methods}

Study site was located at Livestock Research Station of Arid Zone Research Centre, Quetta in Tomagh Range (300 21' N and 680 $36 \mathrm{E}), 15 \mathrm{~km}$ west of Sanjawi of District Ziarat, 1800 meter high from the see level [21] and the climate is Mediterranean type. There is a cold season throughout the winter, from mid-November to end of February in the targeted area where temperature is frequently below the freezing, whereas summers are usually dry and warmer. The average annual rainfall from 1999-2009 is $250 \mathrm{~mm}$ (Figure 1). Temperature maximum and mean minimum (mean) is equal to $32^{\circ}$ $\mathrm{C}, 1^{\mathrm{O}} \mathrm{C}$ respectively. In this area the dominant flora is Ephedra intermedia, Chrysopogonaucheri

Astragalusstocksii, Caraganaambigua, Saccharumgrifithii, Bromus tectorum, Pistaciakhinjak Salvia cabulica, Prunus eburnean, Perowskiaatriplicifoli. Fraxinusxanthoxyloides Poabulbosa, Artemisia quettensis, Cymbopogonjwarancusa (Jones), Ferula oopoda, Ferula costata, Sophoramollis, Ebenusstellata, Tetrapogonvillosa, and Convolvulus spinosus. Soil is silt loam in texture with $42.5 \%$ sand, $36.6 \%$ silt and $20.8 \%$ clay. 


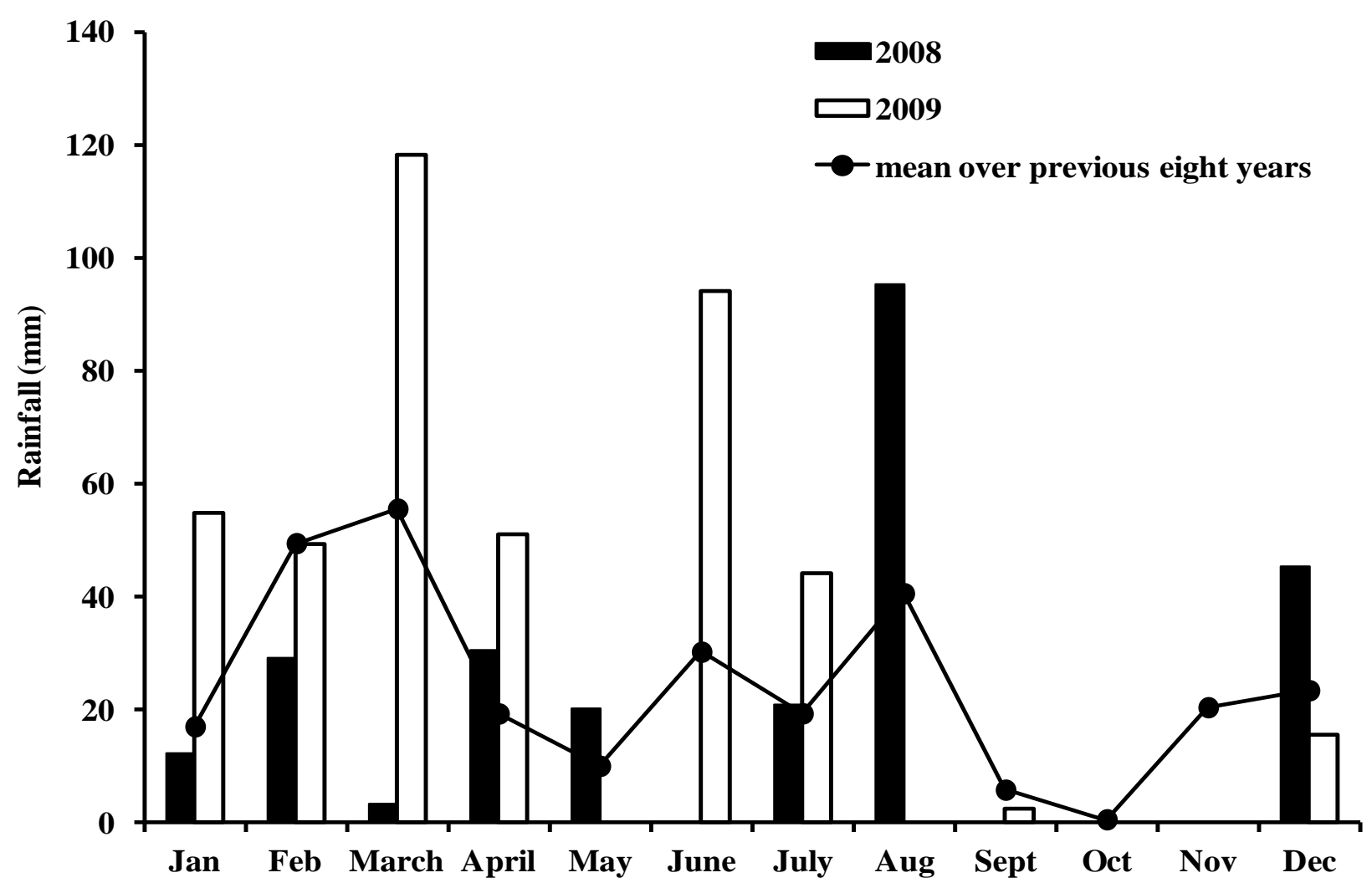

Figure 1. Monthly rainfall during 2008, 2009 and average of over previous eight years

The experimental area was divided in three types; grazed (unprotected), ungrazed (protected) and orchard (of apple tree). The temperature of soil was recorded with digital thermometer from all three sites (Table 1). A pair of PVC tubes, $15 \mathrm{~cm}$ long and $3.5 \mathrm{~cm}$ in diameter, were penetrated to a range $10 \mathrm{~cm}$ in soil in all three experimental sites in first week from May 2009 to -April 2010 for incubation to assess nitrogen mineralization. The initial inorganic nitrogen $\left(\mathrm{NH}_{4}{ }^{+}-\mathrm{N}+\right.$ $\mathrm{NO}_{3}{ }^{-} \mathrm{N}$ ) analysis was done by taking out one tube immediately from the soil and the second tube was left for incubation on the site. All the tubes were covered on the top by a film, having eight $1 \mathrm{~mm}$ diameter holes of plastic piece. Tubes were collected after incubation period of 30 days for inorganic $\mathrm{N}$ analysis of soil within tubes. After removal of stones and coarse roots by hand sorting, from soil cores, thoroughly hand mixing of soil was done. After sieving with a $2 \mathrm{~mm}$ mesh size soil was stored at $4^{\circ} \mathrm{C}$. Finally 10 $\mathrm{g}$ of collected soil sample was dissolved in $50 \mathrm{ml}$ solution $(2 \mathrm{M})$ of $\mathrm{KCl}$ [22] and the same was further analyzed using a UV spectrophotometer for extractable $\mathrm{NO}_{3}$-and $\mathrm{NH}_{4}{ }^{+}$while following laboratory standard method [23]. Net $\mathrm{N}$ mineralization was periodically estimated by using the tube incubation technique [24] during spring i.e March-May, summer i.e. June, July and August and autumn i.e. September-October of the years 2009 and 2010. Further six samples of soil were collected from ungrazed area under the cover of entities Chrysopogonaucheri, and entities of Cymbopogonjwarancusa (3-Replicates; 1 replicate $=$ shared sample of four replicates of both species mixed). Same was doe from 
orchard (Apple) side i.e. six entities of apple tree $(3$ replicates; 1 replication $=$ shared sample of two replications) while from grazed plots, nine entities of Cymbopogonjwarancusa and Chrysopogonaucheri were selected randomly (3-Replicates; 1 replication = shared sample of three replicates of either mixed species). At each collection location a distance of 1 to $10 \mathrm{~m}$ among sampled flora was observed. Every month repeated all the above said procedure in plots of grazed, ungrazed and orchard. $\mathrm{N}$ mineralization on a dry mass basis, throughout growing season, was defined as the change before and after incubation in concentrations of inorganic Nitrogen, net $\mathrm{N}$ ammonification was measured being difference among $\mathrm{NH}_{4}{ }^{+}-\mathrm{N}$ concentrations pre and post of incubation, Whereas the net $\mathrm{N}$ nitrification was measured being difference among $\mathrm{NO}_{3}{ }^{-}-\mathrm{N}$ concentrations pre and post incubation process. For all the incubation periods net amount of mineralized and nitrified $\mathrm{N}$ was summed for calculating total annum net mineralization and mineralization of nitrogen $[25,26]$.

Table 1. Mean for net $\mathrm{N}$-ammonification $\left(\mu \mathrm{g} \mathrm{g}^{-1}\right)$ of the studied lands soil during the months of June 2009 to April, 2010

\begin{tabular}{|c|c|c|c|}
\hline Months & Protected land & Orchard land & Grazed land \\
\hline June & $0.7833^{\mathrm{c}}$ & $0.9633^{\mathrm{b}}$ & $0.0077^{\mathrm{h}}$ \\
\hline July & $0.9533^{\mathrm{b}}$ & $0.8767^{\mathrm{bc}}$ & $0.0093^{\mathrm{h}}$ \\
\hline August & $0.9567^{\mathrm{b}}$ & $0.6167^{\mathrm{d}}$ & $0.0085^{\mathrm{h}}$ \\
\hline September & $0.5667^{\mathrm{d}}$ & $0.6100^{\mathrm{d}}$ & $0.0133^{\mathrm{h}}$ \\
\hline October & $0.5267^{\mathrm{d}}$ & $0.5867^{\mathrm{d}}$ & $0.0063^{\mathrm{h}}$ \\
\hline November & $0.3033^{\mathrm{f}}$ & $0.4833^{\text {de }}$ & $0.0047^{\mathrm{h}}$ \\
\hline December & $0.2200^{\mathrm{f}}$ & $0.3333^{\text {ef }}$ & $0.0057^{\mathrm{h}}$ \\
\hline January & $0.1967^{\text {fg }}$ & $0.2367^{\mathrm{f}}$ & $0.0480^{\text {gh }}$ \\
\hline February & $0.2267^{\mathrm{f}}$ & $0.9233^{\mathrm{bc}}$ & $0.0513^{\mathrm{gh}}$ \\
\hline March & $0.5433^{\mathrm{d}}$ & $0.9867^{\mathrm{b}}$ & $0.0407^{\mathrm{gh}}$ \\
\hline April & $0.6167^{\mathrm{d}}$ & $1.6133^{\mathrm{a}}$ & $0.0247^{\mathrm{h}}$ \\
\hline Mean & $\mathbf{0 . 5 3 4 8}^{\mathrm{b}}$ & $\mathbf{0 . 7 4 8 2}^{\mathrm{a}}$ & $\mathbf{0 . 0 2 0 0}$ \\
\hline
\end{tabular}

No major difference $\mathrm{P}<0.05$ in the mean values preceding same letters, although grand mean values of row, preceding same letters also showing No major difference $\mathrm{P}<0.05$.

\section{Results}

Results showed that there was a significant difference in temperature between different months and land type $(\mathrm{P}<0.05)$. In general, Soil temperature was mostly lower while soil moisture was mostly higher in orchard as compared to the other two sites, while soil moisture was higher in protected than in grazed area (Table 1). ANOVA showed significant difference in mineralization, net ammonification and net nitrification between sites and months $(\mathrm{P}<0.05$, Table 2$)$. The mineralization of $\mathrm{N}$, ammonification and nitrification were higher in orchards than grazed area while protected area had intermediate values for these $\mathrm{N}$ contents ( $\mathrm{P}$ $<0.05$; Tables 3 to 5). 
Table 2. Soil temperature and moisture data in upper 0-15 cm depth

\begin{tabular}{|l|l|l|l|l|l|l|l|l|l|l|l|l|}
\hline \multicolumn{10}{|c|}{ Soil temperature ${ }^{\mathbf{C}}$} \\
\hline & Jun & Jul & Aug & Sep & Oct & Nov & Dec & Jan & Feb & Mar & Apr \\
\hline $\begin{array}{l}\text { Protected } \\
\text { (ungrazed) }\end{array}$ & $34.07^{\mathrm{a}}$ & $32.62^{\mathrm{a}}$ & $26^{\mathrm{b}}$ & $32.35^{\mathrm{b}}$ & $25.24^{\mathrm{a}}$ & $9.37^{\mathrm{b}}$ & $5.71^{\mathrm{b}}$ & $3.98^{\mathrm{a}}$ & $7.90^{\mathrm{a}}$ & $14.20^{\mathrm{b}}$ & $20.43^{\mathrm{b}}$ \\
\hline Orchard & $17.35^{\mathrm{b}}$ & $27.5^{\mathrm{c}}$ & $27.47^{\mathrm{b}}$ & $25.78^{\mathrm{c}}$ & $16.63^{\mathrm{b}}$ & $12.82^{\mathrm{a}}$ & $9.18^{\mathrm{a}}$ & $3.58^{\mathrm{a}}$ & $7.33^{\mathrm{a}}$ & $16.70^{\mathrm{a}}$ & $20.43^{\mathrm{b}}$ \\
\hline Grazed & $35.67^{\mathrm{a}}$ & $28.99^{\mathrm{b}}$ & $30.78^{\mathrm{a}}$ & $33.74^{\mathrm{a}}$ & $21.28^{\mathrm{c}}$ & $10.81^{\mathrm{b}}$ & $8.77^{\mathrm{a}}$ & $4.44^{\mathrm{a}}$ & $8.26^{\mathrm{a}}$ & $16.65^{\mathrm{a}}$ & $22.48^{\mathrm{a}}$ \\
\hline \multicolumn{10}{|c|}{ Soil Moisture } \\
\hline $\begin{array}{l}\text { Protected } \\
\text { (ungrazed) }\end{array}$ & $1.92^{\mathrm{a}}$ & $1.42^{\mathrm{a}}$ & $0.97^{\mathrm{a}}$ & $1.25^{\mathrm{a}}$ & $0.50^{\mathrm{a}}$ & $0.45^{\mathrm{a}}$ & $0.59^{\mathrm{a}}$ & $0.73^{\mathrm{a}}$ & $0.48^{\mathrm{a}}$ & $1.40^{\mathrm{a}}$ & $2.319^{\mathrm{a}}$ \\
\hline Grazed & $0.99^{\mathrm{b}}$ & $0.77^{\mathrm{b}}$ & $0.55^{\mathrm{a}}$ & $0.65^{\mathrm{b}}$ & $0.32^{\mathrm{a}}$ & $0.34^{\mathrm{a}}$ & $0.29^{\mathrm{a}}$ & $0.31^{\mathrm{a}}$ & $0.17^{\mathrm{a}}$ & $0.71^{\mathrm{b}}$ & $1.59^{\mathrm{b}}$ \\
\hline
\end{tabular}

Values within column followed by different letters are different at $\mathrm{P}<0.05$

Table 3. ANOVA (factorial) run on $\mathrm{N}$-mineralization, net ammonification rates and net nitrification $\left(\mu \mathrm{g} \mathrm{g}^{-1}\right)$ of soil in all three selected plots

\begin{tabular}{|c|c|c|c|c|c|c|c|}
\hline \multirow{2}{*}{$\begin{array}{c}\text { Source of } \\
\text { variation }\end{array}$} & & \multicolumn{2}{|c|}{ Mineralization rate } & \multicolumn{2}{c|}{ Ammonification rate } & \multicolumn{2}{c|}{ Nitrification rate } \\
\cline { 2 - 8 } & $\mathrm{dF}$ & F-value & P-value & F-value & P-value & F-value & P-value \\
\hline Months & 10 & 38.49 & $0.0000 * *$ & 36.03 & $0.0000 * *$ & 416.83 & $0.0000 * *$ \\
\hline $\begin{array}{c}\text { Lands } \\
\text { used }\end{array}$ & 2 & 666.44 & $0.0000 * *$ & 513.78 & $0.0000 * *$ & 2.8233 .6 & $0.0000 * *$ \\
\hline $\begin{array}{c}\text { Lands } \\
\text { used } \mathrm{x} \\
\text { months }\end{array}$ & 20 & 25.15 & $0.0000 * *$ & 21.35 & $0.0000 * *$ & 196.02 & $0.0000^{* *}$ \\
\hline Total & 98 & & & & & & \\
\hline
\end{tabular}

NS $=$ Non-significant at 5\% LSD Level. $*=$ Significant at 5\% LSD Level. $* *=$ Significant at $1 \%$ LSD Level

Table 4. Mean for net mineralization $\left(\mu \mathrm{g} \mathrm{g}^{-1}\right)$ of the studied lands soil during the months of June 2009 to April, 2010

\begin{tabular}{|c|c|c|c|}
\hline Months & Protected land & Orchard land & Grazed land \\
\hline June & $0.9333^{\mathrm{c}}$ & $0.9760^{\mathrm{c}}$ & $0.0157^{\mathrm{i}}$ \\
\hline July & $1.1633^{\mathrm{b}}$ & $0.8883^{\mathrm{cd}}$ & $0.0180^{\mathrm{i}}$ \\
\hline August & $1.1900^{\mathrm{b}}$ & $0.6300^{\text {ef }}$ & $0.0187^{\mathrm{i}}$ \\
\hline September & $0.8900^{\mathrm{cd}}$ & $0.6227^{\mathrm{ef}}$ & $0.0140^{\mathrm{i}}$ \\
\hline October & $0.8667^{\mathrm{cd}}$ & $0.5957^{\mathrm{ef}}$ & $0.0097^{\mathrm{i}}$ \\
\hline November & $0.5067^{\mathrm{f}}$ & $0.4883^{\mathrm{fg}}$ & $0.0093^{\mathrm{i}}$ \\
\hline December & $0.3233^{\mathrm{h}}$ & $0.3370^{\mathrm{gh}}$ & $0.0523^{\mathrm{i}}$ \\
\hline January & $0.2900^{\mathrm{h}}$ & $0.2410^{\mathrm{h}}$ & $0.0633^{\mathrm{i}}$ \\
\hline February & $0.3367^{\mathrm{gh}}$ & $0.9353^{\mathrm{c}}$ & $0.0587^{\mathrm{i}}$ \\
\hline March & $0.6667^{\mathrm{e}}$ & $1.0047^{\mathrm{c}}$ & $0.0440^{\mathrm{i}}$ \\
\hline April & $0.7467^{\mathrm{de}}$ & $1.6427^{\mathrm{a}}$ & $\mathbf{0 . 0 2 9 1}$ \\
\hline Mean & $\mathbf{0 . 7 1 9 4}^{\mathbf{a}}$ & $\mathbf{0 . 7 6 0 2}^{\mathbf{a}}$ & \\
\hline
\end{tabular}

No major difference $\mathrm{P}<0.05$ in the mean values preceding same letters, although grand mean values of row, preceding same letters also showing No major difference $\mathrm{P}<0.05$ 
Table 5. Nitrification $\left(\mu \mathrm{g} \mathrm{g}^{-1}\right)$ of the studied lands soil during the months of June 2009 to April, 2010

\begin{tabular}{|l|c|c|c|}
\hline \multicolumn{1}{|c|}{ Months } & Protected land & Orchard land & Grazed land \\
\hline June & $0.1733^{\mathrm{m}}$ & $0.5233^{\mathrm{e}}$ & $0.0080^{\mathrm{q}}$ \\
\hline July & $0.2100^{\mathrm{k}}$ & $0.7700^{\mathrm{a}}$ & $0.0087^{\mathrm{q}}$ \\
\hline August & $0.2333^{\mathrm{k}}$ & $0.6733^{\mathrm{b}}$ & $0.0100^{\mathrm{q}}$ \\
\hline September & $0.3233^{\mathrm{i}}$ & $0.5867^{\mathrm{c}}$ & $0.0027^{\mathrm{q}}$ \\
\hline October & $0.3400^{\mathrm{i}}$ & $0.5433^{\mathrm{d}}$ & $0.0080^{\mathrm{q}}$ \\
\hline November & $0.2033^{\mathrm{ki}}$ & $0.5000^{\mathrm{f}}$ & $0.0050^{\mathrm{q}}$ \\
\hline December & $0.1033^{\mathrm{p}}$ & $0.3733^{\mathrm{h}}$ & $0.0037^{\mathrm{q}}$ \\
\hline January & $0.0933^{\mathrm{p}}$ & $0.1867^{\mathrm{i}}$ & $0.0043^{\mathrm{q}}$ \\
\hline February & $0.1100^{\mathrm{p}}$ & $0.3700^{\mathrm{h}}$ & $0.0120^{\mathrm{q}}$ \\
\hline March & $0.1233^{\mathrm{no}}$ & $0.4133^{\mathrm{g}}$ & $0.0180^{\mathrm{q}}$ \\
\hline April & $0.1300^{\mathrm{m}}$ & $0.4267^{\mathrm{g}}$ & $0.0193^{\mathrm{q}}$ \\
\hline Grand Mean & $\mathbf{0 . 1 8 4 5}^{\mathrm{b}}$ & $\mathbf{0 . 4 8 7 9}^{\mathrm{a}}$ & $\mathbf{0 . 0 0 9 1}^{\mathbf{c}}$ \\
\hline
\end{tabular}

No major difference $\mathrm{P}<0.05$ in the mean values preceding same letters, although grand mean values of row, preceding same letters also showing No major difference $\mathrm{P}<0.05$

\section{Discussion}

Findings in this study are consistent with other published reports [27], who recorded maximum $\mathrm{N}$ mineralization rates in summer [28], and seasonal response was great with high rates occupying in spring and summer while conducting a 6-year experiment on 5 sites. Transformations of soil $\mathrm{N}$ is temperature-dependent biological processes in the rangelands of arid areas [29]. In present study the readings of nitrification to temperature sensitivity of net Nmineralization and ammonification were favoring previous findings of researches [30-32]. Wet season showed higher values of $\mathrm{N}$-mineralization and nitrification rate versus dry season whereas higher mean precipitation per annum causes higher primary production and net nitrogen mineralization $[18,22,33]$. And inorganic pools of $\mathrm{N}$, net $\mathrm{N}$-mineralization and net nitrification were strongly altered by changes of season. The current study in Tomagh proposes that as moisture and temperature of soil is altered by vegetation on $\mathrm{N}$-cycling in rangeland of semi-arid areas. Moreover, microbial biomass (MB) and soil organic carbon (SOC) contents evaluation was not included in this study, but their effects on $\mathrm{N}$ mineralization is ensured. Grazing has positive effects as decrease in SOC and $\mathrm{MB}$ in addition to decreasing infiltration of air and water because amplified compaction [19, 20, 34].

The optimum soil $\mathrm{pH}$ for ammonification ranges between 6.0 to 8.0 and for nitrification and between 7.5 to 8.0 [35]. The $\mathrm{pH}$ of our study area was alkaline i.e. average $7.88 \mathrm{pH}$ values ranged from 6.9 to $8.0 \%$ ). Higher rate of ammonification in our case study as compare to nitrification is unknown. While concluding, greater nitrogen mineralization was analyzed in orchards that possessed a decreased soil temperature and increased soil moisture versus the rest of sites. It is further registered through this research that grazing, soil temperature and moisture are important controlling factors of mineralization of nitrogen [36].

\section{Conclusion}

Nitrogen cycling may be controlled by the soil temperature and soil moisture in Tomagh Semi-arid rangelands. Besides, substantial adverse impact on $\mathrm{N}$-cycling has occurred because of over grazing in area. 


\section{Authors' contributions}

Conceived and designed the experiments: $G$ Bano \& $M$ Islam, Performed the experiments: G Bano, Statistical analyzed the data: G Bano, MJ Durrani \& S Gul, Contributed reagents/ materials/ analysis tools: A Bano, B Akhtar \& S Muhammad, Wrote the paper: G Bano, S Gul \& M Islam.

\section{Acknowledgement}

This research was funded by Agricultural Linkages Program (ALP) of USAID via Pakistan Agricultural Research Council, Pakistan.

\section{References}

1. Sterner RW, Elser JJ (2002). Ecological Stoichiometry: The Biology of the Elements from Molecules to the Biosphere. Princeton University Press, Princeton, New Jersey.

2. Whalen JK, \& Sampedro L (2010). Soil ecology and management. CABI.

3. Vitousek PM \& Howarth RW (1991). Nitrogen limitation on land and in the sea: how can it occur? Biogeochemistry 13(2): 87-115.

4. LeBauer DS \& Treseder KK (2008). Nitrogen limitation of net primary productivity in terrestrial ecosystems is globally distributed. Ecology 89(2): 371-379.

5. Xu Y, Li L, Wang Q, Chen Q \& Cheng $\mathrm{W}$ (2007). The pattern between nitrogen mineralization and grazing intensities in an Inner Mongolian typical steppe. Plant and soil 300(1-2): 289300.

6. Booth MS, Stark JM \& Rastetter E (2005). Controls on nitrogen cycling in terrestrial ecosystems: a synthetic analysis of literature data. Ecological monographs 75(2): 139-157.

7. Antil RS, Lovell RD, Hatch DJ \& Jarvis SC (2001). Mineralization of nitrogen in permanent pastures amended with fertilizer or dung. Biology and fertility of soils 33(2): 132-138.
8. Joshi AB, Vann DR \& Johnson AH (2006). Litter quality and climate decouple nitrogen mineralization and productivity in Chilean temperate rainforests. Soil Science Society of America Journal 70(1): 153-162.

9. Moretto AS \& Distel RA (1999). Effects of selective defoliation on the competitive interaction between palatable and unpalatable grasses native to a temperate semi-arid grassland of Argentina. Journal of Arid Environments 42(3): 167-175.

10. Vitousek PM \& Matson PA (1985). Disturbance, nitrogen availability, and nitrogen losses in an intensively managed loblolly pine plantation. Ecology 1360-1376.

11. Hooper DU \& Johnson L (1999). Nitrogen limitation in dryland ecosystems: responses to geographical and temporal variation in precipitation. Biogeochemistry 46(1-3): 247-293.

12. Steltzer H \& Bowman WD (1998). Original articles: differential influence of plant species on soil nitrogen transformations within moist meadow alpine tundra. Ecosystems 1(5): 464474.

13. Fisk MC \& Schmidt SK (1995). Nitrogen mineralization and microbial biomass nitrogen dynamics in three alpine tundra communities. Soil Science Society of America Journal 59(4): 1036-1043.

14. Schimel JP, Bilbrough C \& Welker JM (2004). Increased snow depth affects microbial activity and nitrogen mineralization in two Arctic tundra communities. Soil Biology and Biochemistry 36(2): 217-227.

15. Zhu WX \& Carreiro MM (2004). Temporal and spatial variations in nitrogen transformations in deciduous forest ecosystems along an urban-rural 
gradient. Soil Biology and Biochemistry 36(2), 267-278.

16. Groffman PM, Driscoll CT, Fahey TJ, Hardy JP, Fitzhugh RD \& Tierney GL (2001). Effects of mild winter freezing on soil nitrogen and carbon dynamics in a northern hardwood forest. Biogeochemistry 56(2): 191213.

17. Bilotta GS, Brazier RE \& Haygarth PM (2007). The impacts of grazing animals on the quality of soils, vegetation, and surface waters in intensively managed grasslands. Advances in Agronomy 94: 237-280.

18. Hamza MA \& Anderson WK (2005). Soil compaction in cropping systems: A review of the nature, causes and possible solutions. Soil and tillage research 82(2): 121-145.

19. Powers RF, Scott DA, Sanchez FG, Voldseth RA, Page-Dumroese D, Elioff JD \& Stone DM (2005). The North American long-term soil productivity experiment: findings from the first decade of research. Forest Ecology and Management 220(1): 3150.

20. Raiesi F \& Riahi M (2014). The influence of grazing exclosure on soil $\mathrm{C}$ stocks and dynamics, and ecological indicators in upland arid and semi-arid rangelands. Ecological Indicators 41: 145-154.

21. Schrama M, Veen GC, Bakker EL, Ruifrok JL, Bakker JP \& Olff $\mathrm{H}$ (2013). An integrated perspective to explain nitrogen mineralization in grazed ecosystems. Perspectives in Plant Ecology, Evolution and Systematics 15(1): 32-44.

22. Atiq-ur-Rehman SR \& Aro RS (1989). Fourwing saltbush as a winter maintenance forage for sheep in upland balochistan. MART/AZR Res. Rep 37.

23. Zhang X, Wang Q, Li L \& Han X (2008). Seasonal variations in nitrogen mineralization under three land use types in a grassland landscape. acta oecologica 34(3): 322-330.

24. Keeney DR \& Nelson DW (1982). Nitrogen - inorganic forms. Methods of soil analysis. Part 2. Chemical and microbiological properties, (methodsofsoilan2): 643-698.

25. Little KM, Arnot L, Du Toit B, Maxfield M, Raison RJ, Connell MJ \& Khanna PK (1987). Methodology for studying fluxes of soil mineral-N in situ. Soil Biology and Biochemistry 19: 521530.

26. Subler S, Parmelee RW \& Allen MF (1998). Earthworms and nitrogen mineralization in corn agroecosystems with different nutrient amendments .Applied Soil Ecology 9(1): 295-301.

27. Trindade H, Coutinho J, Jarvis S \& Moreira N (2001). Nitrogen mineralization in sandy loam soils under an intensive double-cropping forage system with dairy-cattle slurry applications. European Journal of Agronomy 15(4): 281-293.

28. Polglase PJ, Attiwill PM \& Adams MA (1992). Nitrogen and phosphorus cycling in relation to stand age of Eucalypus regnans F. Muell.Plant and soil 142(2): 167-176.

29. Knoepp JD \& Swank WT (1998). Rates of nitrogen mineralization across an elevation and vegetation gradient in the southern Appalachians. Plant and Soil 204(2): 235-241.

30. Dalias P, Anderson JM, Bottner P \& Coûteaux MM (2002). Temperature responses of net nitrogen mineralization and nitrification in conifer forest soils incubated under standard laboratory conditions. Soil 
Biology and Biochemistry 34(5): 691701.

31. Nicolardot B, Fauvet G \& Cheneby D (1994). Carbon and nitrogen cycling through soil microbial biomass at various temperatures. Soil Biology and Biochemistry 26(2): 253-261.

32. Wang C, Wan S, Xing X, Zhang L \& Han X (2006). Temperature and soil moisture interactively affected soil net $\mathrm{N}$ mineralization in temperate grassland in Northern China. Soil Biology and Biochemistry 38(5): 11011110.

33. Wei X, Shao M, Fu X, Ågren GI \& Yin $X$ (2011). The effects of land use on soil $\mathrm{N}$ mineralization during the growing season on the northern Loess Plateau of China. Geoderma 160(3): 590-598.
34. Singh JS \& Kashyap AK (2006). Dynamics of viable nitrifier community, $\mathrm{N}$ mineralization and nitrification in seasonally dry tropical forests and savanna. Microbiological research 161(2): 169-179.

35. Snyman HA \& Du Preez CC (2005). Rangeland degradation in a semi-arid South Africa-II: influence on soil quality. Journal of Arid Environments 60(3): 483-507.

36. Gyaneshwar P, Kumar GN, Parekh LJ \& Poole PS (2002). Role of soil microorganisms in improving $\mathrm{P}$ nutrition of plants. In Food Security in Nutrient-Stressed Environments: Exploiting Plants, Genetic Capabilities (pp. 133-143). Springer Netherlands. 